\title{
A New Species of Fossil Mus (Muridae, Mammalia) from the Late Quaternary Deposits of Narmada Valley, Central India
}

\author{
Bahadur Singh Kotlia ${ }^{1}$, Moulishree Joshi ${ }^{2}$, Lalit Mohan Joshi ${ }^{1}$ \\ ${ }^{1}$ Department of Geology, Kumaun University, Nainital, India \\ ${ }^{2}$ Faculty of Petroleum and Renewable Energy Engineering, Universiti Teknologi Malaysia (UTM), \\ Johor Bahru, Malaysia \\ E-mail: Bahadur.kotlia@gmail.com \\ Received April 18, 2011; revised July 21, 2011; accepted August 29, 2011
}

\begin{abstract}
A new species of fossil Mus (Muridae, Rodentia) is described from the Pleistocene fluviatile deposits of the Narmada valley (Central India). The species, Mus narmadaensis sp. Nov., has a comparatively smaller lower molar which is characterized by a narrow molar with well connected cusps, small anterior expansion of lingual anteroconid, protoconid and metaconid, reduced posterior cingulum in addition to hypoconid and entoconid nearly at the same level. The large $\mathrm{M}_{3}$ has centrally placed bulbous hypoconid. Among the extant species, the present one is closest to $M$. shortridgei in having similarly placed protoconid and metaconid in $\mathrm{M}_{1}$ and a well developed hypoconid in $\mathrm{M}_{3}$.
\end{abstract}

Keywords: Fossil Mus, Late Quaternary, Narmada basin, Central India

\section{Introduction}

Considered to be the most successful groups of living mammals, the murid rodents were originated in the Indian sub-continent about 14 ma ago. At present, they are found all over the world with ability to adapt themselves to varied environmental conditions and show marked species diversity. Today more than $70 \%$ of the murid species are found in the Indo-Australian region, whereas, $26 \%$ murid taxa are found in Africa [1]. The oldest known fossil murid, Antemus chinjiensis was evolved from a cricetid Potwarmus primitivus and was recovered from the Chinji Formation (Siwalik sub-group) in the Potwar Plateau [2]. The study of fossil murids in the Indian subcontinent was initiated by [3-6] and followed by [2] who made significant contribution to the study of Pakistan Siwalik by describing various murid taxa. Subsequently, a sizeable work on the Afghanistan murids was done by [7-11]. As far as the Indian murids are concerned, a number of researches, e.g. [12-26] have shown that the murids were widespread in the country from the Pliocene onwards.

Among the murids, the genus Mus has been reported from various parts of India, e.g., from Kurnool caves
[27], Saketi [19], Kashmir basin [22], Narmada valley $[21,25,28]$, Upper Pleistocene of Bhimtal [23,24], and Dulam [25]. The great diversity of Mus both in terms of number and taxa indicates that the probable place of its origin was the Indian subcontinent. However, an early stock migration to the African continent during MioPliocene time has been suggested [29]. Elsewhere in Asia, Mus has been described from China [30], Crete [31], former USSR [32], Hungary [33], Japan [34] and Thailand [35].

We report here the lower molars of a new species of Mus from the Devakachar section of the Hirdepur Formation of the Narmada deposits.

\section{Area of Study, Litho-Chronology and Fossil Material}

Narmada, the largest river in the Central India, originates at the plateau of Amarkantak ( $\left.22^{\circ} 40^{\prime} \mathrm{N} ; 81^{\circ} 40^{\prime} \mathrm{E}\right)$ and after traversing across the middle of the Indian subcontinent, it joins the Gulf of Cambay near Baroda. The course of the river is controlled by the east-west lineament. Between Bhedaghat $\left(23^{\circ} 8^{\prime} \mathrm{N} ; 79^{\circ} 48^{\prime} \mathrm{E}\right)$ and Hoshangabad $\left(22^{\circ} 45^{\prime} \mathrm{N} ; 77^{\circ} 45^{\prime} \mathrm{E}\right)$, the river forms a trough in 
which about 50m thick Quaternary fluviatile deposits are preserved. Though the deposits are much thicker in the south, the fossiliferous deposits are exposed in the northern fringe in the sections exposed along river Narmada and its tributaries.

The Narmada deposits have been divided into seven lithostratigraphic Formations [36]. The present study area forms a part of the flood plain facies of the Hirdepur Formation (Figure 1(a)), comprising greyish homoge- nous calcareous silt, interlayered with coarse sand, gravel and conglomerate with high degree of calcification. We studied a $17 \mathrm{~m}$ thick profile at Devakachar $\left(23^{\circ} 23^{\prime} \mathrm{N}\right.$; $79^{\circ}$ $07^{\prime} \mathrm{E}$ ), exposed by the Sher River (see Figures 1(a) and (b)). It consists of sand, silt and cemented conglomerate including a fossil bearing horizon. The fossiliferous layer is $0.5 \mathrm{~m}$ in thickness and is composed of medium to coarse grained brownish coloured sand. It is about $9 \mathrm{~m}$ above the base of the profile (Figure 1(b)).

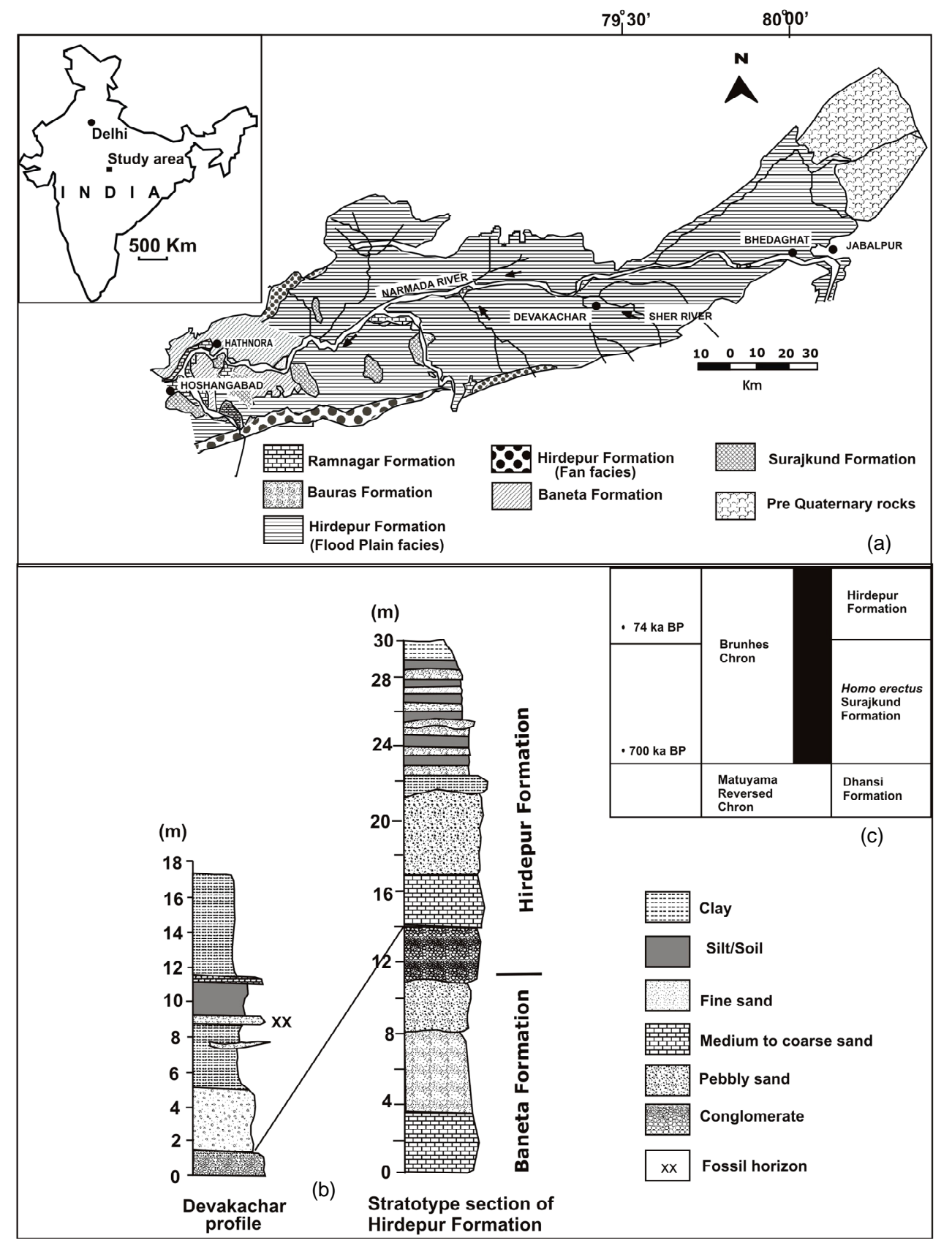

Figure 1. (a) Geological map of the Narmada Valley showing the study sites; modified after [36]; (b) Lithology of the Devakachar sections (present work) and Hirdepur Formation (stratotype section of the Hirdepur Formation is taken from [36]; 1(c) Chronology around Homo erectus locality in the Narmada valley after [26]. 
The basin is very well known for a large number of vertebrate fossils including Elephas, Equus, Bos and several others $[37,38]$. Lately, a discovery of the skullcap of Homo erectus [39] and additional Homo material [40] has made Narmada valley an important site for palaeontological studies. However, the microvertebrates have only been mentioned in a handful of reports, e.g. $[21,41,42]$. The detailed magnetic stratigraphy of the Surajkund and Hirdepur Formations [36,43] and absolute date of the Toba volcanic ash found in the sediments [44] suggest that the boundary of both the formations lies at 74 ka BP and the top of the Narmada sequence is Holocene [40,42]. Several lithics recovered from the Dhansi Formation (see Figure 1(c)) may represent the first unequivocal evidence for an early Pleistocene hominin presence in India [45]. The Homo erectus horizon is only slightly older than the present fossil horizon.

We recovered a large number of microvertebrate remains, such as, murid rodents, lizards and fish from the Devakachar section. The murids are represented by lower molars and incisors. The lizards consist of dentaries, whereas, the cyprinid and channid fishes have teeth and spines. Here, we report only the murid material.

\section{Systematic Palaeontology}

\section{Order: Rodentia}

Family: Muridae

Genus: $M u s$

Mus narmadaensis sp. nov.

Type locality: Devakachar, $120 \mathrm{~km}$ southwest of Jabalpur (Madhya Pradesh).

Horizon and age: The horizon, a medium to coarse grained sand, is Middle to Upper Pleistocene in age.

Referred material: Two $\mathrm{LM}_{1} \mathrm{~S}$ (NAR/1, NAR/2), One $\mathrm{LM}_{3}$ (NAR/3). Broken incisors (NAR/I1-NAR/I6 (Figures 2(a)-(e)).

Etymology: The species has been named after the type area.

Holotype: $\mathrm{LM}_{1}$ (NAR/1, Figure 2(a)).

Paratype: $\mathrm{LM}_{1}$ (NAR/2, Figure 2(b)).

Measurements: See Table 1 for measurements.

\subsection{Differential Diagnosis}

Smallest Mus ever reported, $\mathrm{M}_{1}$ with highly reduced posterior cingulum, $\mathrm{M}_{3}$ with a large second chevron; differing from Mus auctor [2] in having narrower $\mathrm{M}_{1}$ and centrally placed hypoconid in $\mathrm{M}_{3}$; from $M u s$ sp. [2] in having a smaller $\mathrm{M}_{1}$ and from Mus sp. [19] in having a reduced posterior cingulum in $\mathrm{M}_{1}$; from $M$. flynni [19] in having a larger hypoconid in $\mathrm{M}_{3}$; from $M$. jacobsi [22] in having poorly developed labial cingulum and lack of

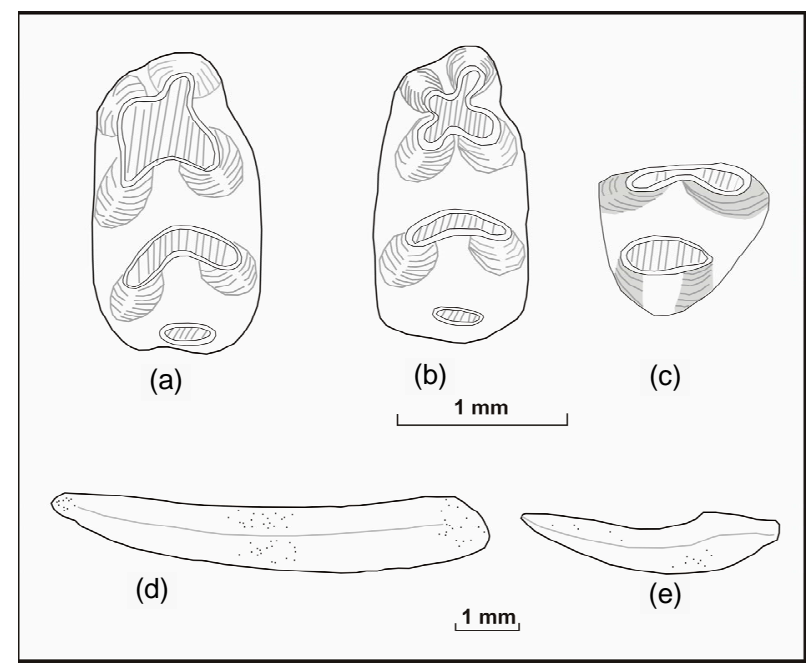

Figure 2. Lower molars of Mus narmadaensis sp. nov. (a)

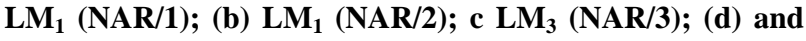
(e), murid incisors (NAR/11 and NAR/16).

Table 1. Length/width measurements of lower molars (mm) in Mus narmadaensis sp. nov.

\begin{tabular}{cccc}
\hline Sp.no. & tooth type & length & Width \\
\hline NAR/1 & $\mathrm{LM}_{1}$ & 1.27 & 0.73 \\
$\mathrm{NAR} / 2$ & $\mathrm{LM}_{1}$ & 1.26 & 0.75 \\
$\mathrm{NAR} / 3$ & $\mathrm{LM}_{3}$ & 0.76 & 0.64 \\
\hline
\end{tabular}

accessory cusps in $\mathrm{M}_{1}$; and differing from $M$. dhailai [23] in having a smaller $\mathrm{M}_{1}$ and much larger hypoconid in $\mathrm{M}_{3}$.

\subsection{Description}

$\mathrm{M}_{1}$ is a small and narrow cusp. The asymmetrical ' $\mathrm{X}$ ' pattern is formed by the four anterior cusps. The labial cusps lie posterior to the lingual cusps in the first chevron. The labial anteroconid is smaller than the anteriorly displaced lingual anteroconid. The cusps are very strongly connected and the connection between the labial anteroconid and protoconid is stronger than between the lingual anteroconid and metaconid. The hypoconid and entoconid are more or less at the same level, the former being slightly bigger than the later. The posterior cingulum is small, oval, transversally flattened and highly reduced. $\mathrm{M}_{1}$ has two roots.

$\mathrm{M}_{3}$ is roughly triangular in outline. The protoconid and metaconid are at the same level and are more or less of the same size in the anterior chevron. The hypoconid and entoconid are merged together to form a bulbous chevron which is centrally placed. The specimen has one complete root. 


\subsection{Comparisons}

Mus narmadaensis sp. nov. can be differentiated from $M$. auctor [2], Mus sp.[19] and M. jacobsi [22] in having the following characters; smaller $\mathrm{M}_{1}$, marginal anterior displacement of lingual anteroconid relative to the labial anteroconid, protoconid and metaconid at the same level, poorly developed labial cingulum and highly reduced posterior cingulum in $\mathrm{M}_{1}$. However, $\mathrm{M}_{3}$ of the present species is bigger than that of $M$. jacobsi and M. auctor. In the $\mathrm{M}_{3}$ of the present species, the hypoconid is centrally placed, whereas, it is displaced lingually in $M$. auctor and labially in $M$. jacobsi.

The present $\mathrm{M}_{1}$ s differ from M. flynni [19] in having a much smaller $\mathrm{M}_{1}$ with lingual anteroconid showing small anterior displacement relative to labial anteroconid, hypoconid and entoconid occupying the same plane and a highly reduced posterior cingulum. $\mathrm{M}_{3}$ of $M$. narmadaensis sp. nov. is larger than that of $M$. flynni and also has a larger hypoconid. The Narmada species is close to Mus sp. [2] in the relative position of cusps in the anterior chevron and a reduced posterior cingulum in $\mathrm{M}_{1}$ but it has a much smaller size. Also, the connection of cusps is much stronger in the Narmada species. The present species is similar to $M$. dhailai $[23,24]$ in the relative position of the labial and lingual anteroconid, protoconid, metaconid and in having a reduced posterior cingulum in $\mathbf{M}_{1}$ and similarly placed hypoconid in $\mathrm{M}_{3}$ but differs from it in having a much smaller $\mathrm{M}_{1}$ and a bigger $\mathrm{M}_{3}$ with a better developed hypoconid (Tables 2 and 3). A comparison of various species of Mus is shown in Figure 3.

\subsection{Enamel Ultrastructure in Murid Incisor}

The rodent enamel microstructure has the highest degree of complexity among mammals [46-50]. In most rodents, the incisor enamel is made up of two layers, an inner portion known as Portio Interna (PI) with intersecting prisms which appear as Hunter-Schreger Bands (HSB) in the longitudinal section, and an outer portion known as Portio Externa (PE) with radial enamel in which the prisms are oriented parallel to each other. The presence of these two layers in the rodent incisor enamel is regarded as a characteristic feature which distinguishes it from lagomorphs where only Portio Interna with HSB is developed [51]. Biomechanically, the HSBs serve as strengthening device inhibiting crack propagation [49,52-54], whereas the radial enamel of the Portio Externa helps to maintain a sharp cutting edge because of its higher resistance to wear [55-57]. The evolution of enamel of the rodent incisor is independent from that of the molar enamel [58].

In rodent incisors, three are three basic types of HSBs, e.g., pauciserial, multiserial and uniserial [46]. Pauciserial HSBs are primitive with highly variable band thickness $[59,60]$. This condition gave rise to the uniserial and multiserial HSBs. In the multiserial enamel, the HSBs are 3-6 prisms wide and are inclined to the Enamel Dentine Junction (EDJ) [61]; whereas, in the uniserial HSBs, the band thickness is reduced to a single prism and the Interprismatic Matrix (IPM) may be parallel or angular to the prism direction [50-61]. In the highly derived uniserial HSBs, the IPM runs rectangular to the prism direction and serves to strengthen the enamel in the third dimension. We studied the enamel ultrastructure of the incisor in the longitudinal section.

\subsection{Lower Incisor of Mus; NAR/I4 (Figures 4(a)-(b))}

The longitudinal section reveals a PI with typical uniserial HSBs which are two prisms thick and a PE with the radial enamel. The HSBs are inclined at an angle of $60^{\circ}$ to the Enamel-Dentine Junction (EDJ) (Figure 4(b)). As

Table 2. Comparative length/width measurements of different species of Mus.

\begin{tabular}{|c|c|c|c|c|c|c|c|}
\hline \multirow[b]{2}{*}{ Name } & \multirow[b]{2}{*}{ Reference } & \multirow[b]{2}{*}{ Locality } & \multirow[b]{2}{*}{ Age } & \multicolumn{4}{|c|}{ measurements (mm) } \\
\hline & & & & \multicolumn{2}{|c|}{$\left(\mathrm{M}_{1}\right)$} & \multicolumn{2}{|c|}{$\left(\mathrm{M}_{3}\right)$} \\
\hline Mus auctor & {$[2]$} & Dhok Pathan Fm., Upper Siwalik & $5.7 \mathrm{ma}$ & 1.472 & 0.928 & 0.680 & 0.800 \\
\hline Mus sp. & {$[19]$} & Tatrot Fm., Upper Siwalik & $2.5 \mathrm{ma}$ & 1.400 & 0.940 & --- & ---- \\
\hline Mus flynni & {$[19]$} & Tatrot Fm., Upper Siwalik & $2.5 \mathrm{ma}$ & 1.687 & 1.040 & 0.617 & 0.653 \\
\hline Mus jacobsi & {$[22]$} & Kashmir basin, NW India & $2.4 \mathrm{ma}$ & 1.550 & 0.956 & 0.560 & 0.520 \\
\hline Mus sp. & {$[2]$} & Dhok Pathan Fm., Pakistan Siwalik & Early Pleistocene & 1.490 & 0.90 & ---- & ---- \\
\hline Mus narmadaensis sp. nov. & present work & Devakachar, Narmada valley & Upper Pleistocene & 1.270 & 0.730 & 0.760 & 0.640 \\
\hline
\end{tabular}


Table 3. Characters and position of various cusps in different species of Mus

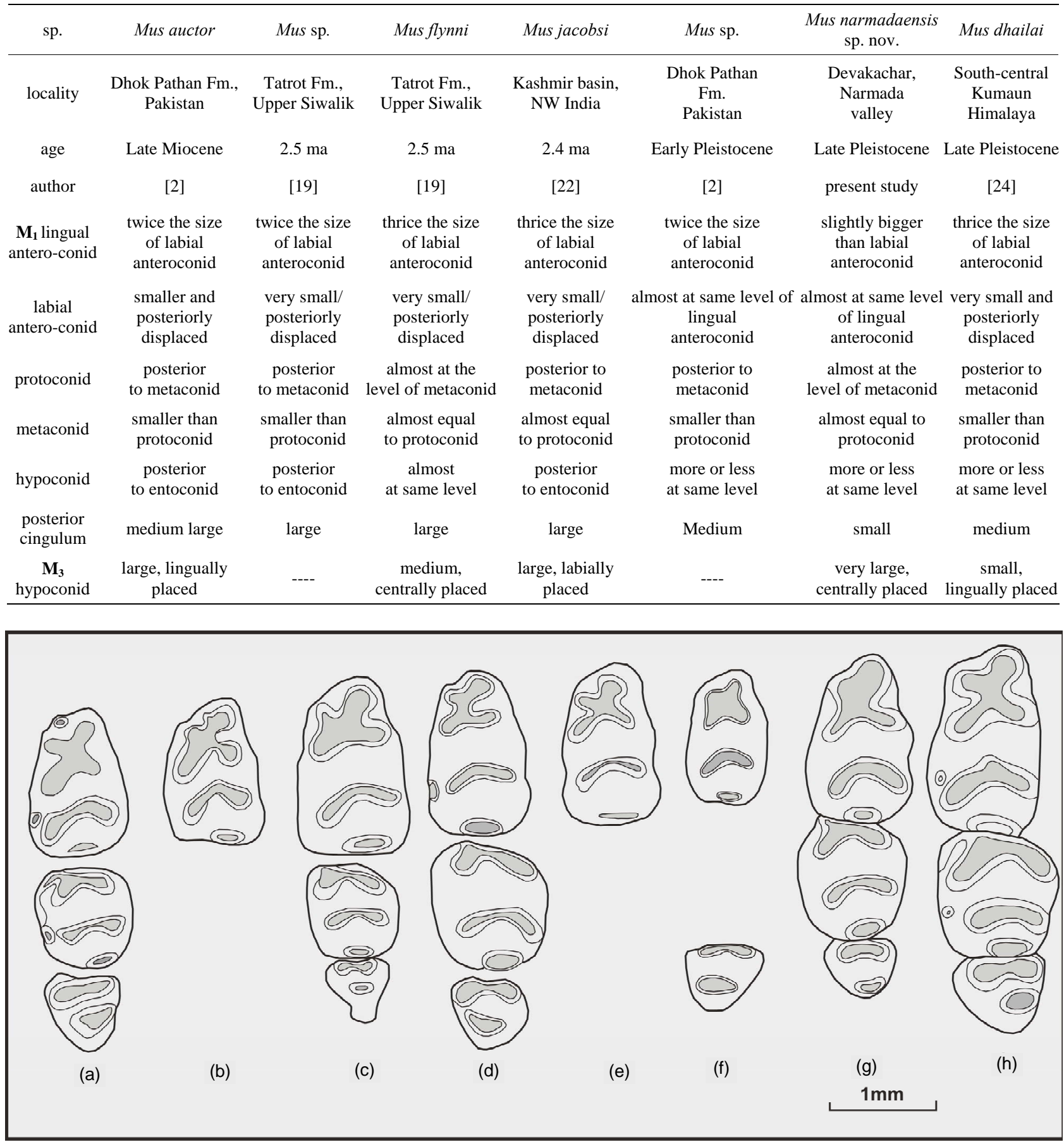

Figure 3. Comparative morphology of the lower molars in various species of Mus. (a) Mus auctor [2]; (b) Mus sp. [19]; (c) M. flynni [19]; (d) M. jacobsi [22]; (e) Mus sp. [2]; (f) M. narmadaensis sp. nov. (present study); (g) M. dhailai [23]; (h) M. shortridgei.

the bands move towards the outer enamel, the angle of inclination gradually decreases from $60^{\circ}$ to $30^{\circ}$ and the prisms become parallel to the EDJ. The prisms of alternating bands intersect at an angle of $90^{\circ}$ at the PE-PI junction and the crystallites of the IP run perpendicular to the long axis of the prisms. The outer and thick enamel is made up of horizontal interlocking prisms. The IP makes an angle of about $90^{\circ}$ with the longitudinal prisms of HSB.

The enamel thickness decreases towards the incisal 


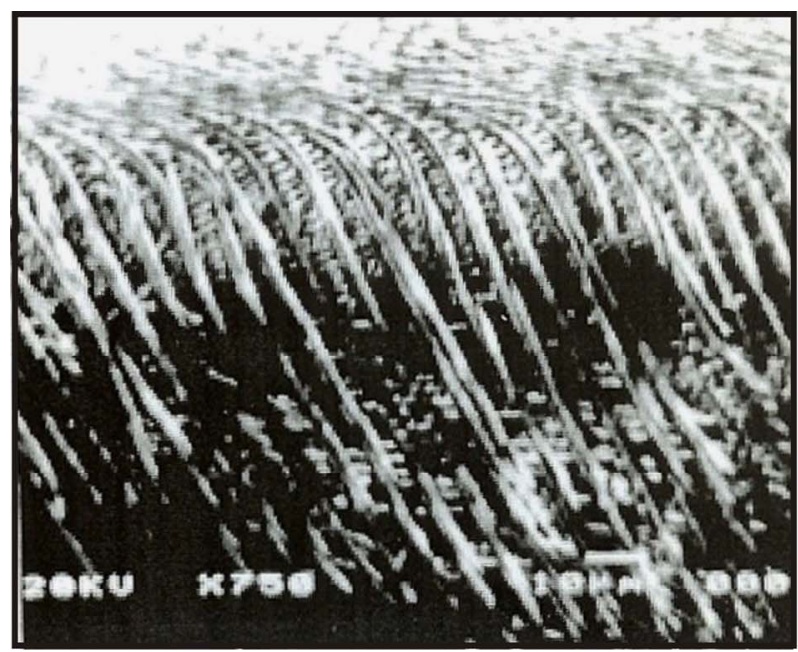

$\mathbf{a}$

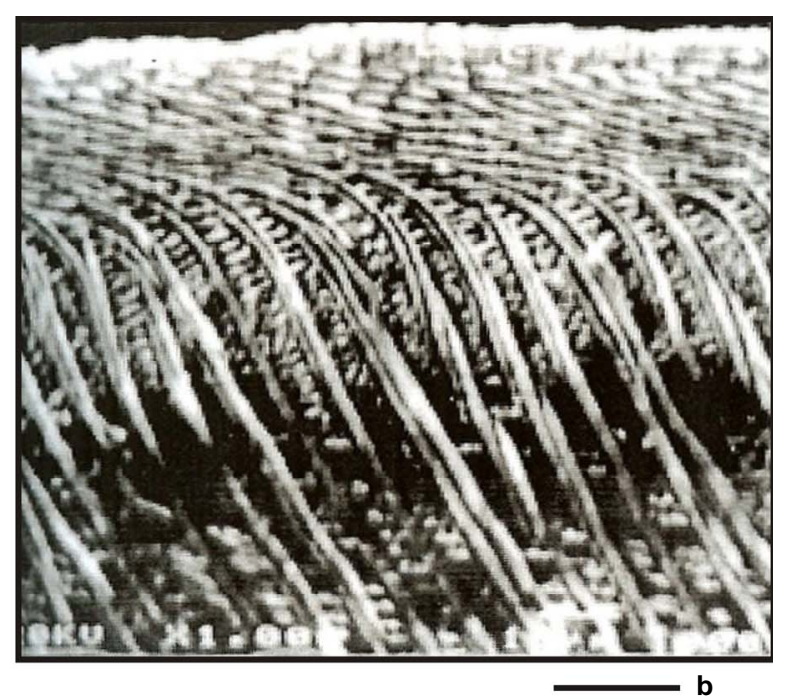

Figure 4. Longitudinal views of the enamel ultrastructure in the lower incisor in Mus (Bar represents 1 mm).

direction (Figure 4(a)). Near the tip of the incisor, the HSBs are more closely spaced just below the outer enamel and the IPM is dense below the PE. The PI is reduced towards the incisal end. At the tip of the incisor, only the radial enamel of the PE is present (Figure 3(a)). The crystallites of the IPM are rectangular and serve to strengthen the enamel in a third dimension. This feature is generally seen in the derived species of murids.

\section{Discussion}

The reduced posterior cingulum in $\mathrm{M}_{1}$ in the present specimen points to its affinity with Pahari section of Mus [13]. In India, Mus is represented by three subgenera, Mus with M. booduga and M. dunni; Pyromys with $M$. saxicola, M. shortridgei and M. platythrix; and Coelomys with M. mayori, M. pahari and M. crociduroides [14]. Coelomys section includes Asiatic species such as $M$. mayori, M. pahari, M. crociduroides and $M$. shortridgei [13]. The Narmada Mus resembles M. pahari in general outline and the placement of cusps in the anterior chevron of $\mathrm{M}_{1}$. However, the second chevron in $\mathrm{M}_{3}$ of $M$. pahari is weakly developed and shows a small lingually placed hypoconid. $M$. crociduroides has a weak second chevron in $\mathrm{M}_{3}$ and is therefore different from the present species. M. mayori differs from $M$. narmadaensis sp. nov. in having a posteriorly displaced protoconid in $\mathrm{M}_{1}$ and a lingually placed and weakly developed hypoconid in $\mathrm{M}_{3}$. Among the extant species, $M$. narmadaensis sp. nov. shows closest resemblance with $M$. shortridgei in having similarly placed protoconid and metaconid in $\mathrm{M}_{1}$ and a well developed hypoconid in $\mathrm{M}_{3}$.

A very small size of the $M$. narmadaensis sp. nov. may be attributed to its getting isolated from the stock at the onset of glacial age during the Pleistocene period. Murids are very sensitive to the climatic changes and it is believed that the onset of cold climatic conditions wiped out several species of murids while some migrated to warmer regions [25]. It may be postulated that $M$. narmadaensis sp. nov. was one of those species that migrated towards Central India from the Lesser Himalayan region at the onset of glaciation. It may have lived there in isolation for a considerable period due to which it could not evolve more progressively although its enamel shows some derived characters as much as in other Pleistocene species.

\section{Acknowledgements}

The study was sponsored by the University Grants Commission and Council of Scientific and Industrial Research, New Delhi. The laboratory facilities were provided by the Department of Geology, Kumaun University, Nainital.

\section{References}

[1] R. Patnaik, “Tooth Enamel Microstructure in Rattus rattus: Functional Implications”, EMSI Bulletin, Vol. 1, No. 1, 2000, pp. 9-15.

[2] L. L. Jacobs, "Fossil Rodents (Rhizomydae and Muridae) from Neogene Siwalik Deposits, Pakistan," Museum of Northern Arizona Press Bulletin Series, Vol. 52, 1978, pp. 1-103.

[3] P. T. Cautley, "Letter Noticing the Discovery of Further Fossils in Vast Quantity in the Siwalik Range," Journal Asiatic Society of Bengal, Vol. 4, 1835, pp. 585-587.

[4] E. H. Colbert, "Siwalik Mammals in American Museum of Natural History," Trans American Philosophical Society Natural History, Vol. 26, 1935, pp. 1-401. 
[5] G. E. Lewis, "Siwalik Fossil Mastomys," American Journal of Science, Vol. 237, No. 4, 1939, pp. 341-344. doi:10.2475/ajs.237.5.341

[6] C. C. Black, "Review of Fossil Rodents from Neogene Siwalik Beds of India and Pakistan,” Paleontology, Vol. 15, No. 2, 1972, pp. 238-266.

[7] S. Sen, "Rongeurs et Lagomorphes du gisement Pliocene de Pul-e Charkhi, Basin de Kabul, Afghanistan,” Bulletin Museum National History Natural, 5th Edition, Vol. 5, No. 1, 1983, pp. 33-74.

[8] S. Sen, M. Sabatier, M. Brunet and E. Heintz, "Decouverte de Rongeurs <<Africans $>>$ dans le Pliocene d' Afghanistan (basin de Sarobi) Implications PaleoBiogeographiques et Stratigraphiques,"Bulletin Museum National History Natural, 4th Edition, Vol. 1, No. 1, 1979, pp. 65-75.

[9] L. D. Brandy, "Etude de Rongeurs muroides du Neogene superieur et du Quaternaire d'Europe, d' Afrique du Nord et d'Afghanistan, Evolution, biogeographie, correlations", These, Be cycle University Science Technical Language Montpellier, 1979, pp. 1-190.

[10] L. D. Brandy, "Rongeurs Muroides du Neogene Superieur d'Afghanistan. Evolution, Biogeographie, Correlations,"Palaeovertebrata, Vol. 11, No. 4, 1981, pp.133179.

[11] L. D. Brandy, L. D. Sabatier and J. J. Jaeger, "Implication Phylogenetique et. Biogeographiques des Derniers decouvertes de Muridae en Afghanistan, au Pakistan et en Ethiopie,”Geobios, Vol. 13, No. 4, 1980, pp. 639-643. doi:10.1016/S0016-6995(80)80007-6

[12] J. R. Ellerman, "Mammalia Rodentia. The fauna of India including Pakistan, Burma and Ceylon,” Zoological Survey of India, Vol. 3, 1961, pp.1-864.

[13] X. Misonne, "African and Indo-Australian Muridae. Evolutionary,” Annals Museum Africa Centrale Zoological Series, Vol. 8, No. 172, 1969, pp. 1-219.

[14] J. T. Marshall, “A synopsis of Asian Species of Mus (Rodentia, Muridae)," American Museum Natural History Bulletin, Vol. 158, 1977, pp. 173-220.

[15] T. J. Roberts, “The Mammals of Pakistan,” Ernest Benn Limited, London, 1977, p.361.

[16] R. Gaur, "First Report on a Fossil Rattus (Murinae, Rodentia) from the Pinjor Formation of Upper Siwalik of India," Current Science, Vol. 55, No. 11, 1986, pp. 542-544.

[17] G. G. Musser, "The Occurrence of Hadromys (Rodentia, Muridae) in Early Pleistocene Siwalik Strata in Northern Pakistan and Its Bearing on Biogeographic Affinities between Indian and Northeastern African Murinae Faunas,” American Museum Novitites, Vol. 2883, 1987, pp. 1-36.

[18] P.Raghavan, "Palaeoenvironment of the Pinjor Formation Based on Microfossil Assemblages and Enamel Uultrastructure of Pinjor and Other Siwalik Primates," Ph.D Thesis, Panjab University, Chandigarh, 1989.

[19] R. Patnaik, "Micropalaeontology, Biostratigraphy and Palaeoenvironmental Analysis of the Siwalik Se- quence in the Saketi Nahan Area (Himachal Pradesh)," Ph.D.
Thesis, Panjab University, Chandigarh, 1991.

[20] R. Patnaik, M. Bahadur, T. Sharma and A. Sahni, “A Comparative Analysis of the Molars of Mus booduga, Mus dunni and Fossil Mus of the Indian Subcontinent, Phylogenetic and Palaeobiogeographic Implications," Current Science, Vol. 65, 1993, pp. 782-785.

[21] R. Patnaik, G. L. Badam and V. Sathe, "Discovery of Microvertebrates from the Pleistocene Deposits of Central Narmada Valley, India,” Current Science, Vol. 68, No. 8, 1995, pp. 828-830.

[22] B. S. Kotlia, "Pliocene Muridae (Rodentia, Mammalia) from Kashmir Basin, Northwestern India,” Neues Jahrbuch für Geologie und Paläeontologie Abhandlungen, Vol. 184, No. 3, 1992, pp. 339-357.

[23] B. S. Kotlia, "Upper Pleistocene Soricidae and Muridae from Bhimtal-Bilaspur Deposits, Kumaun Himalaya, India,” Journal of Geological Society of India, Vol. 46, No. 2, 1995, pp. 177-190.

[24] B. S. Kotlia, "First Upper Pleistocene Mus (Muridae, Rodentia) from the Indian Subcontinent," Acta Zoologica Cracoviensia, Vol. 39, No.1, 1996, pp.251-259.

[25] B. S. Kotlia, "A New Species of Fossil Mus (Rodentia, Muridae) from the Indian Himalaya: Evolutionary and Phylogenetic Implications,” Palaeoworld, Vol. 17, 2008, pp.47-56.

[26] B. S. Kotlia and M. Joshi, “Taphonomy of Late Pleistocene Micromammalian Fauna of Narmada Valley Central India,” Palaeoworld, Vol. 20, No. 1, 2011, pp. 84-91. doi:10.1016/j.palwor.2010.09.017

[27] M. L. K. Murty, "Late Pleistocene Fauna of Kar- nool Caves, South India,” In: A.T. Clason, Ed., Archaeological Studies, North Holland Publishing Company Amsterdam, New York, 1975, pp. 132-138.

[28] M. Joshi, "Palaeontology and Palaeoenvironment of Pleistocene-Holocene Deposits of Narmada Valley between Jabalpur and Hoshangabad, Madhya Pradesh,” Ph.D thesis, Kumaun University, Nainital, 2003.

[29] D. Gerrads, "Rongeurs et Lagomorphs du Pleistocene moyen de la Grotte des Rhinoceros, Carriere Oulalpd Hamida la Casablanca, Maroc,” Neues Jahrbuch för Geologie und Paläeontologie Abhandlungen, Vol. 191, No. 2, 1994, pp. 147-172.

[30] W. C. Pie, "On the Mammalian Remains from Locality 3 at Choukoutien,” Palaeontologia Sinica, Vol. 7, No. 5, 1936, pp. 1-120.

[31] D. M. A. Bate, "New Pleistocene Muridae from Crete," Annales Magazine Natural History, Vol. 11, No. 9, 1942, pp. 41-49.

[32] I. M. Gromov, "Upper Quaternary Rodents of the Samara Bend and Conditions of Preservation," Transactions of Institute of Zoological Academic Sciences, Vol. 22, 1957, pp. 112-150.

[33] D. Janossy, "Vorlaufige Mittelpleis tozane vertebratenfauna der Tarko-Felsnische (N.O. Ungarn),”Annale History National Museum National History, Vol. 54, 1962, pp. 155-176."

[34] K. Kowalski and Y. Hasegawa, "Quaternary Rodents 
from Japan,” Bulletin of National Science Museum Series, Vol. 2, No. 1, 1976, pp. 31-66.

[35] L. Ginsberg, R. Ingavat and S. Sen, "Decouverte d'une fauna d'age Pleistocene Moyen Terminal (loangien) dans le nord de la Thailande,"Comptets Rend Academic Science of Paris, Vol. 294, 1982, pp. 295-297.

[36] M. P. Tiwari and H. Y. Bhai, "Quaternary Stratigraphy of the Narmada Valley,” Geological Survey of India (Special Publication), Vol. 46, 1997, pp.33-63.

[37] G. L. Badam, R. K. Ganjoo and Salahuddin, "Preliminary Taphonomical Studies of Some Pleistocene Fauna from the Central Narmada Valley, Madhya Pradesh, India,” Palaeogeography, Palaeoclimatology, Palaeoecology, Vol. 53, No. 2-4, 1986, pp. 335-348. doi:10.1016/0031-0182(86)90067-2

[38] S. Biswas, "Fossil Mammalia of the Quaternary Sequence of the Narmada Valley: Their Affinity, Age and Ecology," Geological survey of India (Special Publication), Vol. 46, 1997, pp.91-104

[39] A. Sonakia, “The Skull-Cap of Early Man and Associated Mammalian Fauna from Narmada Valley Alluvium, Hoshangabad Area, Madhya Pradesh (India)," Journal of Geological Society of India, Vol. 113, No. 6, 1984, pp. 159-171.

[40] A. R. Sankhyan, "New Fossils of Early Stone Age Man from Central Narmada Valley,” Current Science, Vol. 88, No. 5, 2005, pp. 704-707.

[41] R. Patnaik and A. Sahni, "Record of a Bird Humerus from Upper Pleistocene Narmada Valley Sediments," Palaeontological Society of India, Vol. 39, 1995, pp. 77-79.

[42] B. S. Kotlia and M. Joshi, "Reconstruction of Late Pleistocene Palaeoecology of the Upper Narmada Valley (Central India) Using Fossil Communities,” Palaeoworld, Vol. 17, 2008, pp.153-159. doi:10.1016/j.palwor.2008.06.006

[43] K. V. Rao, S. Chakraborti, K. J. Rao, M. S. V. Ramani, S. D. Marathe and B. T. Borkar, "Magnetostratigraphy of the Quaternary Fluvial Sediments,” Geological Survey of India (Special Publication), Vol. 46, 1997, pp. 65-78.

[44] S. K. Acharyya and P. K. Basu, “Toba Ash on the Indian Subcontinent and Its Implication for the Correlation of late Pleistocene Alluvium," Quaternary Research, Vol. 40, No. 1, 1993, pp. 10-19. doi:10.1006/qres.1993.1051

[45] R. Patnaik, P. R., Chauhan, M. R. Rao, B. A. B. Blackwell, A. R. Skinner, A. Sahni, M. S. Chauhan and H. S. Khan, "New Geochronological, Paleoclimatological, and Archaeological Data from the Narmada Valley Hominin Locality, Central India,” Journal of Human Evolution, Vol. 56, No. 2, 2009, pp.114-133. doi:10.1016/j.jhevol.2008.08.023

[46] V. A. Korvenkontio, "Mikroskopische Untersuchungen an Nagerincisiven, und Hinweise auf die Schmelzstruktur der Backenzahne,"Annales Zoologici Societatis Zoologicae-Botanica, Fennicae, Vanamo, Vol. 2, 1934, pp. $1-274$.

[47] J. H. Wahlert, "Variability of Rodent Incisor Enamel as
Viewed in the Thin Section, and the Microstructure of the Enamel in Fossil and Recent Rodent Groups,” Breviora, Vol. 309, 1968, pp. 1-18.

[48] A. Boyde, "Development of the Structure of the Enamel of the Incisor Teeth in the Three Classical SubOrdinate Groups of the Rodentia,” In: P. M. Butler and K.Y. Joysey, EdS., Development, Function and Evolution of Teeth, 1978, pp. 43-58.

[49] W. V. Koenigswald, "Schmelzmuster and Morphology in the Molars of Arvicolidae (Rodentia) ," Abhandlungen der Senckenbergischen Naturforschenden Gesellschaft, Vol. 539, 1980, pp. 1-129.

[50] W. V. Koenigswald, "Evolutionary Trends in the Enamel of Rodent Incisors,” In: W. P. Luckett, and J. L. Hartenberger, Eds., Evolutionary Relationships among Rodents, a Multidisciplinary Analysis, A Life Sciences, NATO ASI Series, 1985, pp. 403-422.

[51] J. Tomes, "On the Structure of the Dental Tissue of the Order Rodentia,” Philosophical Transactions of the Royal Society, London, Vol. 140, 1850, pp. 529-567. doi:10.1098/rstl.1850.0029

[52] J. Lehner and H. Plenck, “Die Zahne,” In: W. V. Mollendorff, Ed., Handbush de mikroskopischen Anatomie des Menschen, Julius Springer, Berlin, 1936, pp. 449-708.

[53] H. U. Pfretzschner, "Structural Reinforcement and Crack Propagation in Enamel,” In: D. E. Russel, et al., Ed., Memories Museum National History Natural Paris, Vol. 53, 1988, pp. 133-143.

[54] W. V. Koenigswald and H. U. Pfretzschner, "Biomechanics in the Enamel of Mammalian Teeth," In: N. Schmidt-Kittler and K. Vogel, Eds., Constructional Morphology and Evolution, 1991, pp. 113-125.

[55] J. M. Rensberger and W. V. Koenigswald. "Functional and Phylogenetic Interpretation of Enamel Microstructure in Rhinoceros,” Palaeobiology, Vol. 6, No. 4, 1980, pp. 477-495.

[56] M. Fortelius, "Vertical Decussating of Enamel Prisms in Lophodont Ungulates,” In: R. W. Fearnhead and S. Suga, Eds., Tooth Enamel IV, 1984, pp. 427-431.

[57] M. Fortelius, "Ungulate Cheek Teeth: Developmental, Functional and Evolutionary Interrelations," Acta Zoologica Fennica, Vol. 180, 1985, pp. 1-76.

[58] W. V. Koenigswald, "Enamel Modification in Enlarged Front Teeth among Mammals and the Various Possible Reinforcements of the Enamel," Memoires du Muse'um National d' Histoire Naturelle, Vol. C 53, 1988, pp.148165.

[59] T. Martin, "Schmelzmikrostructur in den Inzisiven Altund Neuweltlicher Hystricognather Nagetiere,” Palaeover-tebrata, 1992, p. 1-168.

[60] T. Martin, "Early Rodent Incisor Enamel Evolution: Phylogenetic Implications," Journal of Mammalian Evolution, Vol. 1, No. 4, 1993, pp. 227-254. doi:10.1007/BF01041665

[61] A. Sahni, "SEM Studies of Eocene and Siwalik Rodent Enamels,” Geoscience Journal, Vol. 12, 1980, pp. 21-30. 